\title{
Library Knowledge: The Nigerian Student Perspective
}

\author{
Gilbert Paul Igboechesi, Emmanuel Alison Musa, Enna Godiya Abi, Plangnan Pobish Solomon
}

\begin{abstract}
This paper examines Nigerian students' perception or approach to libraries. It cuts across the primary, secondary and tertiary institutions. The reason for the laxity in library real time usage is the primary driving force that led to the research. The research method adopted for this study was longitudinal method to get the right place of the actual issues without official cover-ups where necessary. Secondary data were also used to buttress the position of the research. The population approached for the longitudinal method was randomly picked at the different levels of schools. Parents were also in place at some point to drive home the true intent they have about their children and the use of libraries. Findings revealed that seeming laxity of both undergraduate and graduate students' perception and attitude about the library is primarily because of the lacuna in their other levels of education before coming to the university. This served as a useful yard stick for the researchers developing workable recommendations that in their opinion will be of immense help to solving it.
\end{abstract}

Index Terms - Library Knowledge, Nigerian Student, Primary School Library, Secondary School Library, Tertiary Library.

\section{INTRODUCTION}

"Library service establish a basic and vital role to achieve sustainable development in the higher educational institution and it's also play a major role by providing required information to improve in the Research and Development (R\&D) sector" (Salarzehi, et al., 2010).

In Nigeria, Libraries are available in some of the country's primary, secondary and most of the tertiary institutions, especially in high profile Private Schools and Federal Unity Schools. They mostly offer the traditional service of lending of books (mostly present in tertiary institutions) and offering a good environment for studying i.e. where students can complete different home works, assignment and other classroom related reading, such as reading for examinations. Most of these libraries have limited space and resources. Most of them also lack the needed technology related facilities and in some cases relevant books to meet the needs of users.

Surprisingly, in Nigeria, awareness of the library is high even among those not using it. The easy way you can identify

\footnotetext{
Gilbert Paul Igboechesi, Assistant Librarian, Library Department, University of Jos, Plateau State, Nigeria

Emmanuel Alison Musa, Assistant Librarian in Training, Library Department, University of Jos, Plateau State, Nigeria

Enna GodiyaAbi, Assistant Librarian in Training, Library Department, University of Jos, Plateau State, Nigeria

Plangnan Pobish Solomon, Assistant Librarian, Library Department,
} University of Jos, Plateau State, Nigeria those that don't use the library is by their perception about the library; they easily associate it with books alone. The ardent user associates it with information and knowledge storage. In all of these levels of education, the importance of libraries are seen as essential to their academic life as an institution but the "life" is not in it proper. This goes to show that there is a disconnect. Reason being that theoretically, they have a primary understanding of what the library stands for but there have been little efforts to make the practicality a reality in the pertinent levels of education in Nigeria. Users share information about their library experiences a lot; they perceive the library as a place offering more of academic related information and therefore an extension of academic study centre. This begs for the inculcation of community libraries. Nigeria scarcely practices it. This level of the library is supposed to bridge the gap between the school libraries, whether it is public or private and the gap that students have before their experience at the tertiary level.

In all of these, the Nigerian Child's exposure to libraries is limited and in most cases absent. The idea of a child, not up to the age of going to the university, visiting a library or using it is highly limited. Most parents don't even give such a taught. The child is most on the terrain of normal school life, lesson in schools and at home etc. This goes to show that a lot more needs to be done to improve library usage in our primary and secondary schools. In the light of the above, the purpose of this study is to examine the perceived gap and laxity among the tertiary students and posit ways of correcting the challenge for the good of the present and next generation.

\section{OBJECTIVES}

In a rapidly changing knowledge-based environment, the place of the Nigerian student is questioned on their attitude towards the libraries, especially at colleges and universities. As a result, it has become increasingly important for libraries and their staff to demonstrate to these students that they are essential and also effective. To achieving this, this study has the following objectives:

1. Establish the needed attitude towards library from the early levels of education.

2. Establish the actual inception of the problem and how it has actually spread to the extent of affecting the level of library usage at the university level.

3. Establish the challenges of libraries in Nigeria, especially that of the Primary, secondary and government public libraries.

4. Recommend solutions to the challenges. 


\section{RESEARCH METHODOLOGY}

The literature was explored by conducting research on the primary reason why most students (at the University of Jos) have limited library knowledge before gaining admission into the university. The researchers understand that this has played a role in their attitude towards library usage. Primary research method (interviews) was carried out on 10 kindergarten Students from 4 different private schools, 25 primary school student from 5 schools, 30 secondary school students from 6 different schools and 50 university students from different faculties and departments from the University of Jos, Nigeria. Longitudinal research method was meticulously employed on teachers of primary and secondary schools, 3 for each, from 4 different schools respectively. Databases, related books, articles, and web searches were also in hand to aid the research as secondary sources. These methods proved to be effective as it provided the needed drive to commence this research.

\section{CONCEPTUAL FRAMEWORK}

Traditionally, the library has a common conception when people are asked to define or give their perception about it. While this is strongly beyond a single conception, it has hardly been watered down in most views. It has always been seen as a place where books are stored and also a quiet place for reading.

Put simply, Library is a room or building containing a collection of books, journals and computers for online access to information. According to Williams (2015), the library is not just about "research" or information literacy... The library must be seen as a place where all aspects of the approaches to Learning are inspired in new ways". He gave examples like the library being a place for "Reflection, Information, literacy, skills, Critical thinking, Creative-thinking, Transfer skills, affective skills, organization skills, collaboration and Communication"

\section{THE NIGERIAN LIBRARY}

When talking about library in Nigeria, one will easily think of the public libraries that are provided by the government, either at state or federal level. Even at that, this is like privileged information to those that know that such actually exist because of the near absence of functional libraries at the centre of students learning process in Nigeria. The knowledge of the library in Nigeria is an issue with different phases. Its place in the Nigerian student is the way it is because of so many anomalies in the educational structure of the country.

Ideally, a student is supposed to be knowledgeable of what the library is all about from the elementary and primary schools proper. This is to inculcate the culture into them. Its importance is supposed to emanate at that point so as that it becomes an impression in them. This means that the various schools we have at the elementary stage is supposed to have a functional library where students can borrow books at that stage to read. This seems not to be the issue in the Nigerian system because of the kind of educational structure we have in place. A close look at the school curriculum and what is expected to cover makes this almost impossible for schools to practice ideal and functional at the primary and secondary levels respectively. There is no time for these students to visit and use the supposed libraries they have, if at all available, for government owned primary and secondary schools, especially the ones owned by the state governments; the schools have no library facility at these beginners level. Students are encouraged and in some cases forced to buy the text books they use at these levels because they are imbedded in school fees most times. They end up not having the need for any other sources because they are naturally told to use their text books for homework and assignments. This also makes such schools lazy in developing the library because it is just there for the government to see and give approval for their schools to run, by extension, students now use it as their reading space during examinations and or other activities of the school.

These schools struggle to meet up with the overloaded curriculum provided by the government that they hardly have free periods and space for the students to use the library. After closing for the day, mostly between 2 and 4pm daily, the students are tired and everyone is expected to leave the school premises. With such scenario, how will a moderate and law abiding elementary or primary school student know about the library and what it offers? Worst still most of these schools in Nigeria don't have librarians, and or library officer(s) that manage their libraries so as to help in the orientation and the space for such, when the system is designed to make such practically impossible. Usually, the attention is mainly on the grades the students get or expected to get and not in the pedigree. Even after going home, most of these students, especially the privileged ones are engaged in private lessons at home by a hired "Lesson teacher". No school, teacher or parent is mindful of the fact that a student actually needs time to read different books outside the needed in school at some point or other books to sharpen their knowledge and understanding on what they are being taught in school. At this level, it automatically makes the child grow with little knowledge on what the library is and what it has to offer.

At the secondary level, this is also translated. These secondary schools have "glorified libraries" primarily for the purpose of government accreditation of their schools for official license to run the school, centres for junior and senior state and federal examinations. In the first place, an average secondary school in Nigeria starts classes each day at 8:00am and ends at $2: 15$ or $2: 30 \mathrm{pm}$ each day. Then the high possibility of prep takes them to $4: 00$ or $4: 30 \mathrm{pm}$. Some of these schools even start classes by 7:30/7:45am daily to meet up with the over jam-packed or grossly bulky curriculum given by the government. The average number of classes for the junior secondary students is between 8 to 9 subjects per day, even when these subjects have supposedly reduced by the education ministry; they are still the same in practice as they still need to be taught by respective teachers to ensure qualitative content. E.g. Basic Science and Technology (BST) is ideally supposed to be handled by three professional teachers in the fields of Integrated Science, Introductory Technology and Computer Science or Information Technology but it is official seen as one subject by the education ministry. So it boils down to the same thing as it 
used to be, if one wants to get it right and prepare the students for a good performance during their Junior and Senior examinations. This actually, is the way most, if not all schools do it. So at the end of the day, the students have up to 14 to 16 subjects to cover. In reality, is this not cumbersome? How does a student have any space for library usage when such is placed? The student, teacher, parent and school management are all focusing on the grades (result) of the student. There is hardly the need to cautiously create the system that will spur the students to library usage. This is why the research and report presentation prepared for EIFL (Electronic Information for Libraries) by TNS RMS East Africa on Perceptions of public libraries in Africa, it was discovered that "Most people associate the Library with traditional book lending and reference services, rather than innovation and technology". This shows that the average African student's understanding about the library is just a place that books a stored for history purpose. Shows that the average African Student understands the library to be a place where books are stored for the purpose of history. Another one by Ashaver and Bem-Bura (2013) opined that:

"Students in these universities (Nigerian Public universities) have a negative perception on the library services rendered by these university libraries. This perception arises from lack of awareness by the students on how to search for information materials and ignorance on information search/retrieval strategies"

This means that the students have little or no knowledge of the intended need for the libraries. As stated before now, the secondary schools don't even have librarians to help such situations. They are not even considered for such positions because the general orientation about education is not tilting towards such grounds.

From the angles of the teachers too, the issue is not good too. They hardly have anything to do with the library, except for relaxation, marking of papers and assignments, writing of their self-expressed weekly frustration called "lesson Plan" and "Lesson Note". The word frustration is used to really paint the right view of these teachers about it. It is largely frustrating because most of these teachers are over worked; most of them teach between 2 to 3 subjects. In most cases, these classes at each level have different arms as well. So if one teacher takes three different subjects in different levels, just imagine what it means to write their lesson plans and notes. How does this help a teacher to use the library and be more productive? The perception of the teachers on the library is also not farfetched as they were also formed into what they are from the same system. The only possible thing is to find quick short cuts and or cut corners, which is what is obtainable in schools that run such system of teaching. You find such in most private schools, operating in such manner, guarantees maximum profit for the owners, while reducing the path to great development in the life of the teachers through the library. What automatically happens to a student that has such experience from the primary and secondary school when he/she gets to the university?

At the tertiary level, you find that the issue is a bit different this is because at the inception of any student's involvement at the university, the place of the library is established. They register as users, offer a compulsory course on it (Use of Library, under the General studies, GST). This is the time that these students begin to get the tip in the ice berg of the library. At this point, they are not easily moved to even make maximum use of the library even after having an idea of what it stands for because by default (even without them knowing) they are used to passing or making it without the library usage. This is so because of the established background. Only a few out of these students actually overcome such education abnormality and step up. In the universities also, the library thrives primarily because of the nature of the students classes. It gives them time to visit the library. At interval they can use the library. The lecturers also give them assignments and areas of research that will prompt them to use the library. Negligible number of these lecturers also use the library to develop their course contents and or outlines to help them lecture better, while also using them to develop their personal research on different issues. Most of them hardly use the library because they prefer to buy their books and equally enrich their study rooms at home; others use the internet connectivity available at the University to access what they want online.

\section{REASONS FOR THE LIBRARY KNOWLEDGE ANOMALY:}

From the discussion so far, it will be fair to list the following as some of the problems facing library knowledge in Nigeria. The problem of:

1. Over bloated curriculum and subjects at the primary and secondary school level.

2. Emphasis on Grades rather than pedigree.

3. Poor Orientation of Students and compulsory subjects on Library at the primary and secondary level.

4. Lack of professional librarians/library officer at the primary and secondary levels.

5. The over bloated work load on teacher of the primary and secondary levels, which hinders them from personally using the library, thereby indulging the students to do same.

6. Glorified, unproductive and poor material-filled libraries in the Nigerian Primary and Secondary schools.

7. Absence of mandatory excesses that will spur students to use the library.

8. Poor funding and orientation at the level of the government public libraries in both the state and federal libraries out of schools.

9. Poor library policy enforcement and lack of routine inspections by the ministry of education.

10. There is the challenge of finances and economic instability in most developing countries as it is with our country Nigeria; low budget policies for the educational sector from the government which militates against provision for and access to good or library facility for our school through the ranks of private and public schools and tertiary institutions. Leading to inadequate availability of library materials, and resources (books, periodical, documents and special collections, electronic resources, furniture, power, personnel etc. to mention but a few.

11. Poor parental knowledge of the library is also a contributing factor. Literacy level among parent varies largely 
as a good number of parent in Nigeria at large do not have knowledge of what the library can offer. The primary reason to this is also tied to their little or no knowledge of the library too. Hence, the lack of inspiration towards their children on the use library for their overall excellence.

\section{CONCLUSION:}

Library's knowledge is a pertinent aspect of learning and information that is centre to the development of the different levels of academic pursuit. This paper has shown that the much concentration on the tertiary institution libraries is so much so that the lower levels of education libraries is barely talked about. In reality, these libraries are actually supposed to be revamped for the ones at the tertiary level to have the needed patronage and growth. These other levels of Library (primary and secondary), need to understand that they form the essential part of the contributions to the achievement of the tertiary institutions' aspirations to providing high quality research and learning environments that meet group and individual needs. As the saying goes;" the journey of a thousand miles begins with a step", in the case of the library, there have been missteps in this journey to a vibrant working and working library for students because, the beginning steps have been greatly ignored.

This research is a wakeup call to all stakeholders in the education industry of Nigeria, they practically need to take steps to revamp the library system in Nigeria, starting from the viability of the libraries in the basic education level (primary and secondary schools), so that the Nigerian student can once again go beyond the class room learning and become a force in the global space.

\section{RECOMMENDATIONS:}

According to Doyle (1995), good library service enhances the quality of education at higher level of institution. She also mentioned that a good library is the heart of a good university which brings academic excellence. To this extent is justifiable to also add that it has gone beyond just academic excellence but for development in all spheres as Salarzehi, et al.; (2010) put it. This naturally solicits the need for;

Community libraries: Community library should be advocated for and strongly given an attention in Nigeria if we are to make a difference in improving the knowledge and use of the library in general. The government and private owners should always include the library in their primary and secondary school design; get skilled personnel(s) to man this libraries and library aware teachers should be employed to help educate these younger students in the use, need, importance and benefits of the library. The government through the ministry of education in conjunction with the Local Government Council should provide functional facilities for the community to further raise the knowledge of the library among the community or local populace. Qualified personnel, librarians and or library officers or assistants must be employed at all times as the case may be.
1. Reduction of education curriculum by the government and inculcation of compulsory library subject at the primary and secondary school levels:

According to Hewlett and Walton (2001):

"Library services are integral to support and guidance to the students through six aspects of provision at the higher education institution. These six aspects of provision are: curriculum design, content and organization; teaching, learning and assessment; student progression and achievement; student support and guidance; learning resources; and quality management and enhancement".

2. Robust orientation to both teachers and students of the Primary and Secondary schools on the need for the use of the library

3. Greater emphasis should be placed on the pedigree of a student rather than grades

4. Compulsory pacts with primary and secondary schools to have in their employ or a valid and working consultant, a professional librarian that will help them do the needful.

5. Regular verification of the libraries at the primary and secondary level to ensure proper operations and rich materials

6. Encourage extracurricular reading and knowledge to expand the knowledge and views of the students

7. On the governments public libraries, interest should be placed on proper funding so as to enable these libraries revive and become functional again. While that is placed, enticing orientation about them should be done, to spur students to wanting to use the library. E.g. quiz and prize by these libraries on books in their libraries and students who have read the chosen books for such quiz. Such students must have a noted and official history of visiting the library for a specific time and spending a specified time while there to qualify for such. Prizes should range from full or half scholarships, monetary stipends for studies etc.

8. The ministry of education should partner with the Librarian Registration Council of Nigeria (LRCN), Library Association (Nigerian Library Association) and other relevant professional bodies, setting up a special task force to see that schools in all levels adhere to the regulation provided by the ministry in building and effectively utilize the library facilities. This committee is to pay a visit to schools in space of two to three years to make certain the said libraries are still very much functional.

9. The librarians, especially the subject librarians, should make it a point of duty to sensitize the staff and students on the role and benefit of using the library. This will go a long way to inform the lecturers and teacher to give assignments to students that will bring them to using the library.

10. Internet resources are key in today's world of information technology. This must be made available to all libraries in all level and, with high speed internet. Operating hours should be very conducive to the users or targeted patrons as well.

11. Librarians and library associations should subsequently organise public lectures and workshops for all level of targeted users or audience in other to enlighten and orientate them on the needs for library usage. 


\section{REFERENCES}

[1] Ashaver, D. and Bem-Bura, M.D (2013). Student's Perception of Library Services in Universities in Benue State. IOSR Journal of Research \& Method in Education (IOSR-JRME)e-ISSN: 2320-7388,p-ISSN: 2320-737X Volume 1, Issue 5 (May. -Jun. 2013), PP 41-48www.iosrjournals.org

[2] Doyle, C. (1995). The perceptions of library service questionnaire (PLSQ): the development of a reliable instrument to measure student perceptions of and satisfaction with quality of service in an academic library. New Review of Academic Librarianship, 1(1), 139-159.

[3] Hewlett, J., \& Walton, G. (2001).Assessing the quality of library and information services for United Kingdom health professionals and students: a comparison of the National Health Service and higher education approaches and the way forward. Performance Measurement and Metrics, 2(2), 81-95

[4] Igboechesi, G.P. and Martyns, E.G. (2020). Mitigating Threat to Academic Libraries: Operational Optimization for Effective Service Delivery. International Journal of Innovative Research \& Development, 9(7), 65-71.

[5] Salarzehi, H., Aramesh, H., \&Ebrahimi, L. (2010). Assessment of service quality at Iran academic libraries with LIBQUAL tool: a case study at University of Sistan and Baluchestan. Interdisciplinary Journal of Contemporary Research in Business, 2(6), 165-179. [23]. Sale, J. E. M. (2007)

[6] TNS, RMS East Africa. Perceptions of public libraries in Africa. EIFL (Electronic Information For Libraries).https://www.eifl.net/perception/perceptions_of_public_ libraries_in_africa_-_full_report_hi.pdf

[7] Williams P. J(2015)Student Agency: A Paradigm Shift in the Role of the Library in Learning. http://thelibraryelement.com/category/library-management/ 